doi: 10.52370/TISC21415NP

\title{
THE IMPACT OF THE CRISIS CAUSED BY COVID-19 ON WOMEN'S ENTREPRENEURSHIP IN TOURISM IN SERBIA
}

\author{
Nebojša Pavlović ${ }^{1}$
}

\begin{abstract}
The aim of this paper is to consider the impact of the crisis caused by Covid-19 on tourism and on women's entrepreneurship in tourism in Serbia. The paper will use the methods of analysis and synthesis, induction and deduction, abstraction, specification and generalization, observation, testing, content analysis, and case study. Based on the available data, it can be concluded that the crisis caused by Covid-19 on the one hand led to (1) the closure of a large number of entrepreneurial companies in the field of tourism, as a result of which a large number of women entrepreneurs lost their jobs; (2) the increased importance of domestic tourism due to the increase in the participation of domestic tourists in total tourist trends. In the future, more attention should be paid to the possibility of training women entrepreneurs in the field of tourism.
\end{abstract}

Key Words: lockdown, women entrepreneurs, tourism, crisis, Covid-19, Serbia

JEL classification: F01, F6, Z3

\section{Introduction}

Economic cycles accompanied by ups and downs are characteristics of a market economy. Historically, the ups and downs of the turning point were natural disasters, and war conflicts; there were also deadly diseases that hit humanity, and which over time, with the development of technology and the health system, reduced their impact on changing the cycle. Of the major declines in the cycle in the recent past, the global recession stands out, which began as a financial crisis in 2007, and soon turned into the deepest

\footnotetext{
${ }^{1}$ Nebojsa Pavlovic, PhD, Associate Professor, Faculty of Hotel Managament and Tourism in Vrnjačka Banja, University of Kragujevac, Vojvodjanska 5A, 36210 Vrnjačka Banja, +381365150021, racapn@gmail.com
} 
recession since the Great Depression in the 1930s. Unlike the finacial crisis in 2007, the announcement of the pandemic of the new disease Covid-19 at the beginning of 2020 indicated the possibility of a new economic recession caused by the health crisis. It is a disease that causes respiratory diseases with symptoms such as cough, fever, and, in severe cases, shortness of breath (Bakar \& Rosbi, 2020). This new strain of the virus, which spread rapidly from China to the rest of the world and which at the time of writing this article recorded over 114 million infected and over 2.5 million dead (Worldometers, 2021) has led to the inevitable slowdown in economic growth.

To prevent the spread of this pandemic, many countries have implemented a lockdown to stop the chain of infection with this new disease (Bakar \& Rosbi, 2020). Given the size of the area to which this virus has spread, it is the largest pandemic in the world history. The single-point virus has never spread to all parts of the world and disrupted lives in all countries. The virus does not bypass developed and rich countries either.

A pandemic can be considered a negative exogenous shock whose effects spread through the economic system, causing an economic downturn and recession. However, there is uncertainty regarding the duration and intensity of the shock, so estimates of future economic trends change daily in terms of the number of infected and dead in individual countries, as well as measures taken by states (Praščević, 2020). Many countries have decided to limit travel due to quarantine, which certainly causes a big drop in consumption, and then a recession.

The Covid-19 pandemic has put unprecedented pressure on the world's tourism industry. The cancellation of the trip has led to a significant reduction in income and liquidity problems for all those involved in tourism. The World Tourism Organization (UNWTO) estimates that international tourism has fallen by $60 \%$, while losses in the global tourism sector amount to 840 to 1,000 billion euros (European Commission, 2020). At the same time, entrepreneurs in the field of tourism were affected by the decline in tourist traffic. In Serbia, between March and May 2020, a large number of travel agencies and more than 30,000 entrepreneurs in tourism were shut down, and the damage was estimated at more than 300 million euros. It is important to point out the fact that women are more often the owners of entrepreneurial shops and micro-enterprises in tourism, the area in which the ban first occurred (Pajvančić et al., 2020). 


\section{Characteristics of female entrepreneurship}

Involvement of women in entrepreneurship - In the total entrepreneurial activity at the age of 18 to 64 , which measures the inclusion of new entrepreneurs, globally, there is about $10.2 \%$ of women, which makes about $3 / 4$ values related to men. The highest rates of entrepreneurial activity are in less developed countries, Africa and Latin America. The lowest rates are in Europe (6\%) and the Middle East regions (9\%). The smallest difference between men and women in starting a new business is in underdeveloped countries. The more developed the countries, the greater the difference between men and women (GEM, 2019).

Intention - According to a GEM (2019) survey, $17.6 \%$ of women globally intend to start an entrepreneurial venture in the next three years. This is almost the same percentage as for men who intend to start an entrepreneurial business (21\%). The underdeveloped countries record the highest percentage of women who would start a self-employed business (almost 38\%) whereas the highly developed European countries record the lowest $(8 \%)$.

Career - In $62 \%$ of cases, women think that entrepreneurship is good for a career. The highest percentage $(71 \%)$ of women who think that it is a good idea to start entrepreneurship is in underdeveloped countries, as opposed to $58 \%$ in highly developed ones. The exception is Sweden where women think that entrepreneurship is a good idea for career development in over $95 \%$. It is interesting that a much higher percentage of women think that entrepreneurship is good for career development (GEM, 2019).

Business interruption - According to a GEM (2019) study, the business shutdown rate is about $10 \%$ lower for women than for men. Women quit their jobs in about $2.9 \%$ and men in $3.2 \%$. Most business interruptions are in underdeveloped countries (over 10\%). In the developed countries of Western Europe, this percentage is about $1.4 \%$. The most common causes of business interruption are bad business (business without profit), lack of finances for further investment in an entrepreneurial venture, retirement, family reasons, large levies, unregulated relations in this sphere of business. Financial reasons are in the highest percentage (about 50\%) predominant for business interruption. 


\section{The importance of women's entrepreneurship in tourism}

Women entrepreneurs have great potential, which is reflected not only in the opportunities that would be created through the achievement of gender employment but also in the fact that women bring diversity to innovative processes. More women are leading to a variety of perspectives. Solutions to market inequalities are not only offered by male entrepreneurs, with a masculine mind-set. The solutions offered by women entrepreneurs and their innovations may be different from those reached by men so that women's entrepreneurship can also be seen as part of diversification. In the area of developing countries, women entrepreneurs are mostly engaged in the field of services, such as tourism, ICT, health, care, and nursing, etc. These are sectors that have great potential. With innovations that originate from personal creativity and a new way of thinking, consumer involvement and gender differences, the potential for promoting women entrepreneurs is obvious (Vrbanac, 2018).

In Serbia, the most important women's association is the Association of Business Women of Serbia, which offers its members training for beginners and women who already run a company, a mentoring program, meetings, consultations on legal solutions in terms of respect for the role of women, research and publications, promotion of the successful examples of women, and regional and international cooperation. A Network of Women Entrepreneurship Ambassadors has been established in Serbia, whose role is to promote women's entrepreneurship at the national level through addresses to women in schools and colleges, media campaigns, conferences, establishing business ties, and participation in the European Network of Women Entrepreneurship Ambassadors, participation in econferences, campaigns, etc. Also, the Network of Mentors of Women's Entrepreneurship of Serbia has been formed, which consists of mentors successful entrepreneurs who will provide assistance to women entrepreneurs in the initial phase of business or those who have difficulties in running their own business.

When it comes to women's entrepreneurship in tourism, it is important to emphasize that the majority of the workforce in tourism are women. Given the wide geographical reach and the wide range of necessary skills, tourism has the opportunity to lift women out of poverty, equip them with the skills they need, to provide them with dignity and sustainable employment. The fact is that the tourism industry has great potential. However, according to a report by the World Tourism Organization, statistics show that there is no 
complete equality in the position of male entrepreneurs and female entrepreneurs in tourism. Namely, most women are concentrated in jobs that are of a lower level, such as cleaning, serving, and cooking. At the same time, for these jobs, women are paid on average 10-15\% less than men. In addition, a large number of women are engaged in unpaid jobs in tourism. They do this by supporting family households in the form of invisible customer service providers, maids, cleaners, etc. (Responsible Travel, 2020).

\section{The impact of the Covid-19 crisis on women entrepreneurs}

There are many types of crises that can jeopardize the work of women entrepreneurs (GEM, 2019):

- natural disasters;

- accidental disasters;

- technological disasters;

- theft and vandalism;

- problems with lack of electricity or fuel;

- economic crises that can turn into a disaster for a country's economic system;

- terrorism;

- epidemiological catastrophes caused by pandemics and diseases.

Although we left for the end, the pandemic, caused by the Covid-19 virus, was the cause of catastrophic consequences for the economy of every country in the world. Unfortunately, they are always the most endangered in situations like this, the weakest ones who come first to strike when bad times start. This has happened to many women entrepreneurs engaged in some specific activities who (again, unfortunately) were the first to be hit by the pandemic and could not continue working or continued working at a much-reduced capacity. At that level of business, they could not make the minimum profits that would keep them in business. The state tried, but it is certain that it failed, to remedy all the burning problems caused by the epidemiological crisis. In accordance with the abovementioned, two questions arise. What is the impact of the pandemic on the tourism sector and what is the opinion of women entrepreneurs about the measures implemented to reduce the issue? What challenges did women entrepreneurs face in the tourism sector? 
"For women in business in Serbia, the key percentage is 30\% - so many of them are in management positions, and the same percentage are entrepreneurs. This is in line with the world average, and in relation to the USA, almost 30\% more" (Kukić, 2019). When it comes to the impact of Covid-19 on women's entrepreneurship, the tourism sector is most affected, followed by agriculture. Layoffs are much lower in other sectors, as other branches were not so vulnerable. On the other hand, the number of employed women in health care has increased.

\section{The impact of Covid-19 on women entrepreneurship in tourism}

The fact is that the pandemic has disrupted the lives of every citizen in the world, but it is also a fact that not all categories are equally affected: rich and poor, young and old; whites and other races; men and women. On the contrary, due to the pandemic, all the inequalities that existed increased, and it mostly affects those categories that were already endangered and vulnerable (Mršević \& Janković, 2020).

It is very important to point out that the Covid-19 virus has a disproportionate impact on female entrepreneurship (Madgavkar et al., 2020). In Serbia, in the form of a factor that leads to the deterioration of the economic position of women, it is possible to point out stereotypical attitudes, which also have an impact on the gender-specific economic consequences of the crisis that women are experiencing. Namely, it is not about new attitudes, but about traditional social stereotypes about the role of women, which have been strengthened again by the crisis. These are attitudes that can have repercussions on current decisions, both when it comes to the organizational, institutional level, and when it comes to the family (for example, when making a decision about who will keep the job). On that occasion, the traditional gender-discriminatory stereotype comes to the fore, according to which men "have more rights" to work compared to women, when there is little work (Mršević \& Janković, 2020).

Compared to men, women's jobs and livelihoods are more affected by the pandemic prize, primarily the economic effects associated with Covid- 19 . The reason for this lies in the existing gender inequality, but also the fact that due to Covid-19 the rate of job loss in women is about $1.8 \%$ higher than in men (Madgavkar et al., 2020). The impact of the pandemic on business: $75 \%$ of companies owned by women report a drop in income. As the biggest challenge they face due to the pandemic, $69 \%$ of respondents 
state a decrease in demand, i.e. a smaller number of customers (Blic, 2020), which is the case with tourism.

Most women entrepreneurs work in high-risk sectors where the impact of the Covid-19 virus epidemic is high. In particular, we are talking about the tourism, education, counselling, and trade sectors. Like any crisis, this great crisis can affect women's entrepreneurship in tourism in two ways. In the first case, many entrepreneurial companies in tourism were shut down, as a result of which a large number of women entrepreneurs lost their jobs. On the other hand, the fact is that the offer of destinations at the national level has become more and more extensive. During 2020, as much as 60\% of the total tourist movements were driven by domestic tourists (Turistički svet, 2021), and due to the existing restrictions on international travel, it is expected that this number will increase over time.

Therefore, the question arises as to whether the destinations will be able to respond to the needs and expectations of new travellers from Serbia and whether they will be ready to improve the level of supply of products and services, in order to exceed the expectations of tourists and visitors? Given the great importance of this issue when it comes to the development of domestic tourism, the team of the Center for Tourism Research and Studies launched a project of training and education for women entrepreneurs, which aimed at enabling participants to acquire new skills that will provide them the opportunity to improve their business. The training had the greatest focus on women who are the bearers of rural households and offer destinations. Special emphasis was placed on managing the destination after the crisis, creating joint tourist products, and in cooperation with the portal for booking accommodation in rural tourism, selo.rs, it was agreed to provide access to educational materials created by the Center (Turistički svet, 2021).

According to the research conducted by the Agency for Gender Equality and Women's Empowerment, the payment of non-refundable funds was best assessed by women entrepreneurs, and then the payment of taxes and contributions on salaries and wage compensations was postponed until January 2021. Women entrepreneurs stated that during the next period, special tax reliefs intended for entrepreneurs should be provided, in the form of reduction of property tax, VAT rates, taxes, and contributions. At the same time, women entrepreneurs believe that the existing measures have been beneficial, but that there is a lack of measures that would ensure the remediation of much deeper economic consequences that will manifest 
themselves in the coming period. In addition, women entrepreneurs are of the opinion that the measures introduced did not adequately respond to the real needs of businessmen in the tourism sector and were not adapted to small businesses (Agency for Gender Equality and Women's Empowerment, 2020).

When it comes to the number of employees in tourism in Serbia, it amounted to 4,525 in January 2020, 67\% of which were women - 3,031. In January 2021, the number of employees in tourism was 2,987, 2,000 of which were women. According to the presented data, it can be concluded that the number of employees in tourism decreased by 1,538, 1,000 of which are women (Stevanović, 2021).

\section{Entrepreneurship in Serbia at the time of the pandemic}

There are 278,670 entrepreneurs in Serbia. An estimated 600,000 people work in these companies. The number of women entrepreneurs is about $33 \%$ (over 91,000). According to the data taken from Agencija za privredne registre Republike Srbije (Serbian business registers agency) (2021), entrepreneurial companies from the following areas were most often deleted (a total of 20,014 companies were deleted):

- computer programming - as the state announced, the number of such companies dealing with information technologies should have grown. However, due to the problems with the payment of taxes that arose sometime in early September 2020, many owners of such companies decided to delete them. In the coming period, the lack of these companies, which employed a lot of people (especially young people), will certainly be felt;

- restaurant activities and mobile catering facilities - it is common for many such companies to be established and closed down;

- taxi transport - many people are engaged in taxi services while the vehicles used in these companies last. And these firms are very fluid and their numbers are changing very fast;

- beverage preparation and serving services - the difficult operation of catering facilities have drastically reduced the number of companies engaged in this activity;

- consulting activities.

At the same time, during the epidemiological crisis, in 2020, companies from the following areas were most often established $(27,461$ in total) (Statistical Office of the Republic of Serbia, 2021): 
- activities of restaurants and mobile catering facilities (1,746 companies were established and 1,426 of these types of companies were deleted);

- consulting activities (1,406 companies established and 906 closed);

- the activity of hairdressing and beauty salons;

- road freight transport;

- maintenance and repair of motor vehicles.

\section{What does a woman entrepreneur in Serbia look like and what can endanger the work of a woman entrepreneur?}

According to Popović-Pantić (2014), women entrepreneurs, who own more than $50 \%$ of companies, are actively involved in the company's business as managers, and create employment for themselves and others. In the description of a woman entrepreneur in Serbia, we were helped by the research conducted by Ipsis Strategic Marketing with the Visa company. These are some characteristics of a woman entrepreneur in Serbia and her company (Ipsos Strategic Marketing, 2020):

- works independently;

- mostly does not rely on family business (only $27 \%$ of women entrepreneurs had someone in the family who ran their own business and they continued that business; as many as $91 \%$ of women entrepreneurs state that this is their first own business);

- it is the first independent business lasting more than 10 years;

- half of women entrepreneurs have only one employee (on average, women entrepreneurs in Serbia have 2.7 employees);

- the average age of an entrepreneurial firm is 12 years (the largest number of firms is up to 5 years old);

- generally, 5,000 euros are needed to start an entrepreneurial venture in Serbia;

- the greatest fear among women entrepreneurs comes from a possible financial loss (this fear was much greater than the fear that the family would be neglected);

- the biggest motivator is freedom (as many as 56\% of women entrepreneurs answered that it is a strong motivator), while other motives include the possibility of higher earnings, dissatisfaction with previous jobs, unemployment, flexible working hours, job satisfaction (Pavlović, 2017);

- women entrepreneurs find it most difficult to find funding, while other obstacles include: the difficulty of making a decision to start a business, problems finding information relevant to starting a business, problems 
finding a business partner, and the fact that administration and paperwork are unknown to new women entrepreneurs;

- women entrepreneurs work on average close to 6 days a week (55\% of them, and as many as $20 \%$ of women entrepreneurs work all 7 days), while the nature of work determines the time spent at work (e.g. jobs in tourism require weekly and year-round engagement);

- the working day of women entrepreneurs lasts on average about 9 hours (30\% of them spend this time at work).

\section{Impact of pandemics on the tourism sector and measures to reduce the consequences caused by the crisis}

The global tourism industry has faced significant losses and damages in previous decades as a result of a series of unfortunate events. These events often involve natural disasters, man-made hazards, and epidemic crises (Polyzos et al., 2020). The outbreak of Covid-19 left strong consequences on the tourism sector. This highly contagious virus has led to serious questions about the survival of the tourism sector, both present, and future (Kaushal \& Srivastava, 2021). Due to the pandemic, various public health measures were implemented in order to prevent the spread of the disease. These measures include testing, quarantine, social distance, restrictions on movement and travel, campaigns aimed at getting people to stay in their homes. The mentioned measures did not bypass any country in the world, while at the same time they left a strong mark on the economies of those countries, depending on the manner and intensity of their introduction and implementation. Tourism, defined by Koncul (2009) in the form of a set of different and interconnected activities of economic and non-economic importance that are directly or indirectly related to mass tourist migration, is directly affected by these measures by the tourist offer and tourist demand. In order to create a certain market, it is necessary to meet supply and demand, and in the case of their dislocation, which is a characteristic of tourism arising from its basic definitions, and the impossibility of creating new distribution channels, because the physical presence of tourists in a particular tourist destination is a conditio sine qua non (a state without which one cannot), there is a collapse of the market. Tourist demand always travels towards the tourist offer, and various forms of movement restrictions directly prevent the fulfilment of this condition. Such new circumstances in the tourism market are the cause of the emergence of numerous domestic and international texts that study various aspects of the impact of the pandemic on tourism. Each author concentrates on a narrow area, as a result of which the space for research, despite a large 
number of texts, is still very wide (Bakar, \& Rosbi, 2020; Baum \& Hai, 2020; Farzanegan et al., 2020; Gössling, et al., 2020; Hoque et al., 2020; Jones \& Comfort, 2020; Polyzos \& Samitas et al., 2020; Qiu et al., 2020; Yang et al., 2020).

Table 1: Change in the number of foreign tourist arrivals in the world and Europe by months in 2020 compared to the same months in 2019

\begin{tabular}{|c|c|c|}
\hline Month & World (change in\%) & Europe (change in\%) \\
\hline January & $-1 \%$ & $5 \%$ \\
\hline February & $-16 \%$ & $2 \%$ \\
\hline March & $-64 \%$ & $-61 \%$ \\
\hline April & $-97 \%$ & $-98 \%$ \\
\hline May & $-96 \%$ & $-96 \%$ \\
\hline June & $-91 \%$ & $-88 \%$ \\
\hline July & $-80 \%$ & $-71 \%$ \\
\hline August & $-77 \%$ & $-67 \%$ \\
\hline September & $-79 \%$ & $-72 \%$ \\
\hline October & $-83 \%$ & $-77 \%$ \\
\hline November & $-88 \%$ & $-87 \%$ \\
\hline December & $-85 \%$ & $-85 \%$ \\
\hline Average & $-\mathbf{7 4 \%}$ & $-\mathbf{7 1 \%}$ \\
\hline
\end{tabular}

Source: World Tourism Organization - UNWTO, (2021), International tourism and Covid-19, https://www.unwto.org/international-tourism-andCovid-19, (08 February 2021)

According to the UNWTO, in 2020, the world recorded $74 \%$ fewer arrivals of foreign tourists compared to the previous year. Observed by months, the largest decrease was recorded during April 2020 (-97\%) (UNWTO, 2021), which is a direct consequence of the lockdown that made travel impossible. On the other hand, observed on the continents, the largest decrease was recorded in Asia and the Pacific (-84\%), and the smallest in the United States (69\%) (UNWTO, 2021). Changes in the number of arrivals of foreign tourists in the world and in Europe compared to the same months of the previous year are shown in Table 1 .

The tourism sector in Serbia is an industry that has suffered and will suffer huge losses due to the crisis caused by Covid-19. When it comes to foreign exchange inflows, these losses are estimated at 300 million euros for the period from March to November 2020, taking into account the very high growth of tourist traffic during January and February 2020, which indicated that 2020 will be one of the best years in tourism. During the first two 
months of 2020, the growth of total arrivals in Serbia was 21\%, and the percentage of overnight stays was 22\% (Trivić, 2020).

Table 2: Tourism of Serbia in 2020 compared to 2019

\begin{tabular}{|c|c|c|c|c|}
\hline & $\begin{array}{c}\text { Number of } \\
\text { tourist } \\
\text { arrivals } \\
\text { (in\%) }\end{array}$ & $\begin{array}{c}\text { The number } \\
\text { of overnight } \\
\text { stays (in\%) }\end{array}$ & $\begin{array}{c}\text { Number of } \\
\text { overnight stays } \\
\text { of domestic } \\
\text { tourists (in\%) }\end{array}$ & $\begin{array}{c}\text { Number of } \\
\text { overnight by } \\
\text { foreign } \\
\text { tourists (in\%) }\end{array}$ \\
\hline January & $+24.2 \%$ & $+25.1 \%$ & $+22.5 \%$ & $+28.7 \%$ \\
\hline February & $+18.9 \%$ & $+20.1 \%$ & $+20.8 \%$ & $+18.6 \%$ \\
\hline March & $-56 \%$ & $-45.7 \%$ & $-37.2 \%$ & $-58.3 \%$ \\
\hline April & $-97.7 \%$ & $-96.4 \%$ & $-94 \%$ & $-95.8 \%$ \\
\hline May & $-87.6 \%$ & $-82.2 \%$ & $-76.4 \%$ & $-94.4 \%$ \\
\hline June & $-52.5 \%$ & $-43.3 \%$ & $-17.2 \%$ & $-84.4 \%$ \\
\hline July & $-50.5 \%$ & $-35.9 \%$ & $-3.2 \%$ & $-85.3 \%$ \\
\hline August & $-34.3 \%$ & $-17.1 \%$ & $-23.1 \%$ & $-83.3 \%$ \\
\hline September & $-43.1 \%$ & $-22.9 \%$ & $-18.8 \%$ & $-76.3 \%$ \\
\hline October & $-49.3 \%$ & $-37.5 \%$ & $-14.9 \%$ & $-66.2 \%$ \\
\hline November & $-63.3 \%$ & $-46.6 \%$ & $-28.9 \%$ & $-68 \%$ \\
\hline December & $-67.1 \%$ & $-55.9 \%$ & $-75.6 \%$ & $-75.6 \%$ \\
\hline
\end{tabular}

Source: Statistical Office of the Republic of Serbia, 2020a; 2020b; 2020c; 2020d; 2020e; 2020f; 2020g; 2020h; 2020i; 2020k; 2021

A state of emergency was declared in Serbia on March 15, 2020, and on that occasion, all borders for traffic were closed and international passenger flights were cancelled, which was reflected in the arrival of foreign tourists. According to the data shown in Table 2, it is concluded that the largest decline in all observed parameters was recorded during April 2020 - the number of tourist arrivals (-97.7\%), the number of overnight stays ($96.4 \%)$, the number of domestic tourist nights (-94\%) and the number overnight stays of foreign tourists $(-95.8 \%)$ (Statistical Office of the Republic of Serbia, 2020d). During January 2021, compared to January 2020 , the number of tourist arrivals decreased by $40.4 \%$, while the number of overnight stays decreased by $34.8 \%(-10.7 \%)$, the number of domestic tourist nights, $-66.9 \%$ number of overnight stays of foreign tourists (Statistical Office of the Republic of Serbia, 2021).

Serbia has implemented certain measures aimed at amortizing losses in the tourism sector caused by the decline in visits by foreign tourists. One of the measures is the distribution of 160,000 vouchers $(60,000$ more than in the previous year) which provided support to domestic tourism (Trivić, 2020). 
On the other hand, the state set aside 1.2 billion dinars in the form of direct non-refundable aid for city hotels (Ivaniš \& Pavlović, 2017). The condition for receiving 350 euros per bed and 150 euros per person was not to lay off more than $10 \%$ of workers by the end of 2020 . The biggest problem faced by travel agencies is bank guarantees, i.e. their height. For that reason, in November 2020, the Government of Serbia approved 150 million dinars for subsidies for insurance policy premiums to travel agencies. The aim of this measure was to provide assistance to agencies, primarily smaller travel organizers who are also most vulnerable to the crisis (Ristev-Dušej, 2020).

\section{Conclusion}

Serbia is characterized by a qualitative and quantitative base for tourism development. The nature of the attraction, with the achieved level of accommodation and other capacities, points out that numerous types of tourism could be developed, especially if the diversity of the landscape, as well as the natural potentials of Serbia, are taken into account. The development of tourism during the period before the crisis speaks in favour of numerous effects, which were, in an important way, built into the economic and social development of Serbia.

At the same time, the Covid-19 pandemic has caused great concern and uncertainty, which is more or less faced by all social groups. However, there are differences in the perception of the source of concern. As women entrepreneurs are a vulnerable category in the market and as they are particularly affected by the economic changes caused by the pandemic, it is not surprising that in such circumstances they primarily care about economic survival, while health concerns are second to none. Uncertainty about the duration of the pandemic heightens concerns about the economic consequences of the pandemic on business, especially for women entrepreneurs engaged in service activities, such as tourism.

Based on a review of the literature, it is possible to conclude that the impact of the crisis caused by Covid-19 is twofold. On the one hand, the crisis has led to the closure of a large number of entrepreneurial companies in the field of tourism, as a result of which a large number of women entrepreneurs have lost their jobs. In contrast, due to the lockdown, the offer of destinations at the national level has become increasingly important, given the fact that domestic tourists accounted for the largest share of total tourist movements, which provided an opportunity for women entrepreneurs to thrive. To this end, certain types of seminars, workshops, 
and training were conducted to help women entrepreneurs acquire new skills that will give them the opportunity to improve their knowledge. This training mostly benefited women entrepreneurs engaged in rural tourism, which expanded in Serbia in 2020, and which certainly needs to be improved.

\section{References}

1. Agencija za privredne registre Republike Srbije (Serbian business registers agency), (2021), http://www.apr.gov.rs, (25 January 2021).

2. Agency for Gender Equality and Women's Empowerment, (2020), Uticaj COVID-19 pandemije i mera za njeno sprečavanje na preduzetnice $u$ Srbiji [Impact of the COVID-19 pandemic and measures for its prevention on women entrepreneurs in Serbia], https://www.secons.net/ files/publications/118-publication.pdf, (29 January 2021).

3. Bakar, N. A. Rosbi, S. (2020). Effect of Coronavirus disease (COVID19) to tourism industry. International Journal of Advanced Engineering Research and Science, Vol. 7, No. 4, 189-193.

4. Baum, T., Hai, N. T. T. (2020). Hospitality, tourism, human rights and the impact of COVID-19. International Journal of Contemporary Hospitality Management, Vol. 32, No. 7, 2397-2407.

5. Blic, (2020), Preduzetnici u fokusu. Đorđević: Visa je globalno prepoznala značaj malih $i$ srednjih preduzeća, a sada im pomažemo i u Srbiji [Entrepreneurs in focus. Djordjevic: Visa has globally recognized the importance of small and medium enterprises, and now we are helping them in Serbia as well], https://www.blic.rs/biznis/preduzetnici-u-fokusudjordevic-visa-je-globalno-prepoznala-znacaj-malih-i-srednjih/shvw0s2, (09 January 2021).

6. European Commission, (2020), Factsheet: The EU helps reboot Europe's tourism, https://ec.europa.eu/commission/presscorner/api/files/ attachment/865487/factsheet-eu-heps-reboost-tourism-v1.pdf.pdf, January 2020).

7. Farzanegan, M. R., Gholipour, H. F. Feizi, M., Nunkoo, R. Eslami Andargoli, A. (2020). International tourism and outbreak of coronavirus 
(COVID-19): A cross-country analysis. Journal of Travel Research, Vol. 41, No. 4, 340-347.

8. Global Entrepreneurship Monitor - GEM, (2019), Women's entrepreneurship report, https://www.gemconsortium.org/report/gem20182019-womens-entrepreneurship-report, (09 January 2021).

9. Gössling, S., Scott, C. D. Hall, M. (2020). Pandemics, tourism and global change: A rapid assessment of COVID-19. Journal of Sustainable Tourism, Vol. 29, No. 1, 1-20.

10. Hoque, A., Shikha, F. A., Hasanat, M. W., Arif, I. Abu Bakar A. H. (2020). The effect of coronavirus (COVID-19) in the tourism industry in China. Asian Journal of Multidisciplinary Studies, Vol. 3, No. 1, 52-58.

11. Ipsos Strategic Marketing, (2020), https://www.ipsos.com/sr-rs, (25 January, 2021).

12. Ivaniš, M. Pavlović, N. (2017). Universal values and ethical behaviour of hotel management in Croatia, International Journal for Quality Research,Vol. 10, No. 2, 677-690.

13. Jones, P. Comfort, D. (2020). The COVID-19 crisis, tourism and sustainable development. Athens Journal of Tourism, Vol. 7, No. 2, 75-86.

14. Kaushal, V. Srivastava, S. (2021). Hospitality and tourism industry amid COVID-19 pandemic: Perspectives on challenges and learnings from India. International Journal of Hospitality Management, Vol. 92, 102707.

15. Koncul, N. (2009). Ekonomika i turizam [Economics and tourism], Mikrorad d.o.o., Zagreb.

16. Kukić, Z. (2019). Žensko preduzetništvo - kako stojimo? [Women's entrepreneurship - How do we stand?], https://talas.rs/2019/04/29/zenskopreduzetnistvo/, (16 April 2021).

17. Madgavkar, A., White, O., Krishnan, M., Mahajan, D. Xavier, A. (2020). COVID-19 and gender equality: Countering the regressive effects, https://www.mckinsey.com/featured-insights/future-of-work/Covid-19and-gender-equality-countering-the-regressive-effects, (21 January 2020). 
18. Mršević, Z. Janković, S. (2020). Žene preduzetnice Srbije u vreme pandemije virusa korona [Women entrepreneurs of Serbia during the corona virus pandemic]. In P. Jovanović \& S. Stojković-Zlatanović (Ed.), Izazovi održivog razvoja u Srbiji i Evropskoj Uniji, Institute of Social Sciences, Belgrade, 46-63

19. Pajvančić, M., Petrušić, N., Nikolin, S., Vladisavljević, A. Baćanović, V. (2020). Rodna analiza odgovora na COVID-19 u Republici Srbiji [Gender analysis of responses to COVID-19 in the Republic of Serbia], Misija OEBS-a u Srbiji i Ženska platforma za razvoj Srbije 2014-2020, Belgrade.

20. Pavlović, N. (2017). The Role of Social participants in the Evaluation of Teachers at Univerity in Serbia, Transylvanian Review, Vol. XXVI, No. 1, 74-90.

21. Polyzos, S., Samitas, A. Spyridou, A. E. (2020). Tourism demand and the COVID-19 pandemic: an LSTM approach, Tourism Recreation Research.

22. Popović-Pantić, S. (2014). Žensko preduzetništvo u Srbiji: evolucija od socijalne ka ekonomskoj kategoriji [Women's entrepreneurship in Serbia: evolution from social to economic category]. Poslovna ekonomija, Vol.8, No. 2, 143-162.

23. Praščević, A. (2020). Ekonomski šok pandemije Covid-19 prekretnica u globalnim ekonomskim kretanjima [The economic shock of the Covid-19 pandemic - a turning point in global economic trends]. Ekonomske ideje i praksa, Vol. 37, 7-22.

24. Qiu, R. T. R., Park, J., ShiNa, L. Haiyan, S. (2020). Social costs of tourism during the COVID-19 pandemic. Annals of Tourism Research, Vol. 84, 102994.

25. Responsible Travel, (2020), Women entrepreneurs in tourism. Empowering women through tourism, https://www.responsibletravel.com/ holidays/women-entrepreneurs-in-tourism/travel-guide, (15 April 2020).

26. Ristev-Dušej, T. (2020). Korona virus, turizam i turističke agencije u Srbiji: Svega imamo, ali nemamo izvesnost [Corona virus, tourism and 
travel agencies in Serbia: We have everything, but we have no certainty], https://www.bbc.com/serbian/lat/srbija-54776805, (15 January 2021).

27. Statistical Office of the Republic of Serbia, (2020a), Tourist turnover January 2020, https://publikacije.stat.gov.rs/G2020/Pdf/G20201044.pdf, (01 February 2020).

28. Statistical Office of the Republic of Serbia, (2020b), Tourist turnover - February 2020, https://publikacije.stat.gov.rs/G2020/Pdf/G20201081.pdf, (01 February 2020).

29. Statistical Office of the Republic of Serbia, (2020c), Tourist turnover March 2020] https://publikacije.stat.gov.rs/G2020/Pdf/G20201111.pdf, (01 February 2021).

30. Statistical Office of the Republic of Serbia, (2020d), Tourist turnover - April 2020, https://publikacije.stat.gov.rs/G2020/Pdf/G20201132.pdf, (01 February 2021).

31. Statistical Office of the Republic of Serbia, (2020e), Tourist turnoverMay 2020, https://publikacije.stat.gov.rs/G2020/Pdf/G20201175.pdf, (01 February 2021).

32. Statistical Office of the Republic of Serbia, (2020f), Tourist turnoverJune 2020, https://publikacije.stat.gov.rs/G2020/Pdf/G20201205.pdf, (01 February 2021).

33. Statistical Office of the Republic of Serbia, (2020g), Tourist turnover - July 2020, https://publikacije.stat.gov.rs/G2020/Pdf/G20201238.pdf, (01 February 2021).

34. Statistical Office of the Republic of Serbia, (2020h), Tourist turnover - September 2020, https://publikacije.stat.gov.rs/G2020/Pdf/G20201290.pdf, (01 February 2021).

35. Statistical Office of the Republic of Serbia, (2020i), Tourist turnoverOctober 2020, https://publikacije.stat.gov.rs/G2020/Pdf/G20201319.pdf, (01 February 2021). 
36. Statistical Office of the Republic of Serbia, (2020j), Tourist turnoverNovember 2020, https://publikacije.stat.gov.rs/G2020/Pdf/G20201348.pdf, (01 February 2021).

37. Statistical Office of the Republic of Serbia, (2021), Tourist turnover January 2021, https://publikacije.stat.gov.rs/G2021/Pdf/G20211046.pdf, (27 February 2021).

38. Stevanović, K. (2021). Korona virus, ugostiteljstvo i turizam u Srbiji "Nije dobro, ali moglo je i mnogo gore" [Corona virus, catering and tourism in Serbia "It's not good, but it could have been much worse"], https://www.bbc.com/serbian/lat/svet-56198019, (16 April 2021).

39. Trivić, B. (2020). Turizam u Srbiji trpi milionske gubitke [Tourism in Serbia suffers millions in losses], https://www.slobodnaevropa.org/a/ turizam-srbija-pandemija-korona/30558905.html, (03 February 2021).

40. Turistički svet, (2021), Odgovor na krizu u turizmu uzrokovanu koronavirusom - Jačanje kapaciteta mladih i žena preduzetnica u periodu posle pandemije [Responding to the tourism crisis caused by the coronavirus - Strengthening the capacity of young people and women entrepreneurs in the post-pandemic period], https://www.turistickisvet.com/vesti/obrazovanje/odgovor-na-krizu-uturizmu-uzrokovanu-koronavirusom--jacanje-kapaciteta-mladih-i-zenapreduzetnica-u-periodu-posle-pandemije.html, (15 February 2021).

41. Vrbanac, M. (2018). Barijere i pokretači ženskog preduzetništva u Srbiji [Barriers and drivers of women's entrepreneurship in Serbia], Univezitet Union - Nikola Tesla, Fakultet za graditeljski menadžment, Beograd.

42. World Tourism Organization - UNWTO, (2021), International tourism and Covid-19. https://www.unwto.org/international-tourism-and-Covid19, (08 February 2021).

43. Worldometers, (2021), Coronavirus update, https://www.worldometers.info/ coronavirus/, (28 February 2021).

44. Yang, Y., Zhang, H. Chen, X. (2020). Coronavirus pandemic and tourism: Dynamic stochastic general equilibrium modeling of infectious disease outbreak. Annals of Tourism Research, Vol. 83, 102913. 